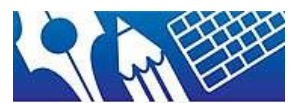 \\ Australasian \\ Association \\ of Writing \\ Programs
}

TEXT SPECIAL ISSUES

Number 60 October 2020

ISSN: 1327-9556 | https://www.textjournal.com.au/

\section{Transnational encounters}

\section{Bashabi Fraser}

To cite this article: Fraser, B 2020 'Transnational encounters', in J Sarangi \& A Walker (eds) Indian-Australian exchanges through collaborative poetic inquiry, TEXT Special Issue Number 60, TEXT: Journal of writing and writing courses 24, 2 (October):

http://www.textjournal.com.au/speciss/issue60/Fraser.pdf 


\title{
Edinburgh Napier University
}

\author{
Bashabi Fraser
}

\section{Transnational encounters}

\begin{abstract}
:
This paper reflects on the transnational journeys poets make as they cross and re-cross nationstate boundaries. They are sensitively alert to their need for adjustment in their new place of relocation after being displaced from 'homes that have given ... [their] lives roots, stability, and meaning' (Ghosh 2016: 54). The distance of time and space lends an objectivity to the diasporic observations of transnational writers and their peripheral positioning often leads to an alignment with other marginal lives, enabling a profound understanding and empathy with those faced with displacement and rupture from a familiar habitat and way of life. Transcontinental writers today are acutely aware of 'a planet-spanning ... arena of activity' (Vertovec 2009: 3) as they confront the environmentalism of the poor, the slow violence (Nixon 2013) inflicted on vast swathes of humanity by 'capitalism and empire' (Ghosh 2016: 146). In their poetry, they are writer activists, bearing witness and testimony to the devastating effects of power which have accelerated climate change, widening social disparities. In these transnational encounters, they 'displace the centre' from the periphery which 'return(s) to rewrite the history and fiction of the metropolis' (Bhabha 1990), as evident in Dominique Hecq's verse and my poetic responses and reflections.
\end{abstract}

Biographical note:

Bashabi Fraser is a poet, children's writer, translator, editor and academic. She has a $\mathrm{PhD}$ in English Literature and is Professor Emerita of English and Creative Writing and Co-founder and Director of the Scottish Centre of Tagore Studies (ScoTs) at Edinburgh Napier University, a Royal Literary Fund Fellow and Honorary Fellow, Centre for South Asian Studies, University of Edinburgh. She has authored and edited 22 books which include several poetry collections and poetry anthologies, has been widely anthologised and has several academic articles/chapters in international publications. Bashabi is the recipient of the title of Outstanding Woman of Scotland conferred by the Saltire Society in 2015. Her many awards include Kavi Salam from Poetry Paradigm and Voice of the Republic in India in 2019; the Word Masala Foundation Award for Excellence in Poetry in 2017; Women Empowered: Arts and Culture Award in 2010 and the AIO Prize for Literary Services in Scotland in 2009. Bashabi is Honorary Vice President of the Association of Scottish Literary Studies (ASLS) and an executive committee member of Scottish PEN, Writers at Risk Committee and Poetry Association of Scotland, Ambassador for Federation of Writers (Scotland), Trustee of the Kolkata Scottish Heritage Trust and Director on the Board of the Patrick Geddes Memorial Trust. Bashabi is Chief Editor of the peer reviewed academic and creative e-journal, Gitanjali and Beyond. Bashabi lives and writes in Edinburgh. Her next poetry collection entitled, Habitat, is with her publisher.

Keywords:

Transnational - dislocation - displacement - journeys - environment - climate change 


\section{Introduction}

At the heart of the transnational encounter is a quest to connect, to interpret and intervene in a new 'place', the 'elsewhere' where the poet has arrived, while grappling with one's own creative space, the 'somewhere' within, as questions are raised by the historic and recent human interventions that are constantly threatening to change what the poet wills to create - a sustaining and sustainable space and place. In his 'Introduction' to Nation and Narration, Bhabha asks 'What kind of a cultural space is the nation with its transgressive boundaries and its 'interruptive' interiority?' (Bhabha 1990: 5). He concludes, 'America leads to Africa, the nations of Europe and Asia meet in Australia: the margins of the nation displace the centre; the peoples of the periphery return to rewrite the history and fiction of the metropolis' (Bhabha 1990: 6). This is the response of many diasporic writers in a postcolonial world, who contribute to revisionist social history as writer activists, retelling the story of transformed places and lives, informed by their own experience of displacement and relocation in new spaces of creativity. They are acutely conscious of the '[d]ifferentials of power between and within nations ... [as being] probably greater today than they have ever been'. They know that '[ $t$ ]hese differentials are, in turn, closely related to urban emissions. The distribution of power in the world therefore lies at the core of the climate crisis' (Ghosh 2016: 146). The transnational encounter bears witness to two interconnected significant 'rifts' between 'capitalism and empire' responsible for the present 'landscape' of climate change (Ghosh 2016: 146).

'Transnationalism describes a condition in which, despite great distances and notwithstanding the presence of international borders ... certain kinds of relationships have been globally intensified and now take place paradoxically in a planet-spanning yet common - however virtual - arena of activity (Vertovec 2009: 3). Rob Nixon writing on the environmentalism of the poor, speaks about slow violence, the violence that occurs out of sight and is gradual, entailing delayed destruction 'dispersed across time and space' (Nixon 2013: 2). It is not spectacular, but a process that is attritional, accretive, incremental and exponential. Nixon gives some examples like 'climate change, the thawing cryosphere, toxic drift ... deforestation, the radio-active aftermath of wars, acidification' that are responsible for slow violence (Nixon 2013: 2), and for our purposes here, deforestation and the thawing cryosphere are significant realities. Like Ghosh, Nixon's reference is to literature, and in this case, the writer activists who have utilised their imaginative agility and worldly ardour to help amplify the mediamarginalised causes of the environmentally dispossessed', emphasising 'the gulf between the enclaved rich and the outcast poor' (Nixon 2013: 3, 8).

This is what has led me to understand, identify with and respond to Dominique Hecq's poems which spring from the global perspective of a transnational writer who journeys through her new chosen place in Australia, while trying to retrieve the stories of its displaced 'old' inhabitants and coming to terms with her own experiences. In her poems, I have felt that she is conscious of the significance of place and spaces which need protection today from the denuding power of commerce and market driven economics which threaten the ecosystems that need defending for a sustainable future in order to revert the slow violence inflicted on the vulnerable. 
When I was put in touch with Dominique Hecq, I was very excited as her many publications and awards proved how much she is respected as a writer. I found we had much in common. She has moved across continents, has a multi-linguistic background, has studied Literature, obtained a $\mathrm{PhD}$ in English, has an interest in interdisciplinary studies and is a poet who voices her concerns about places and people and the urgency of maintaining a viable relationship between mankind and nature for a sustainable environment. These are concerns which have permeated my poetry too. This awareness of a globalized economy which is facilitated by concealment of the 'truth' by policy makers which operates through the complicity of whole societies today, is recognised by Amitav Ghosh as 'patterns of evasion' which he predicts will make this era known as 'the time of the Great Derangement' (Ghosh 2016: 11).

As Dominique comes from the French-speaking part of Belgium and has specialized in Germanic studies, she has been open to a multilingual world, which echoes my own experience of coming from India where the linguistic diversity is an enriching experience. This has drawn me to the three poems Dominique sent me which I read and reread with deep interest, trying to uncover their many layered signification. I have found them engaging, intriguing and moving.

Of my poems which I had initially sent Dominique, she chose three which resonated with her. Dominique sent me her own responses to my poems, but many life-changing personal issues intervened and interrupted my work and I was unable to respond in time. I decided to withdraw from this innovative creative project. However, both the coordinators, Amelia and Jaydeep, were sympathetic and understanding and gave me a much-needed reprieve, suggesting I write a single-authored article as a way back into the project, which I very much appreciate. Dominique has generously agreed to continue our interrupted poetic dialogue, which gave me a fresh impetus and I responded to her three original poems with my own, which Dominique has graciously acknowledged and accepted.

Both Dominique and I are transnational poets who have moved worlds; the language of our creative expression is English, which is not our mother tongue; we know the disruption that comes with displacement, understand exile as 'the unhealable rift forced between a human and a native place' (Said 2000: 173) and 'rifts' between 'capitalism and empire' (Ghosh 2016: 146), but we are prepared to traverse continents in our poetry with a continuing interest in our environment which provides a habitat we cherish and express in verse.

The themes that stand out for me in Dominique's three poems are those of journeys: transnational, geographical and internal, of writing from the margins, environmental concerns, of the vulnerability of lives threatened by powerful policy makers, of a changing landscape, place names with identifiable histories, of relationships, loss and the creative process itself.

\section{First pair of poems: 'Traces' and 'Hasdeo Arand'}

I have never been to Australia, but the continent has come alive to me through friends who are from there, through literature, news coverage, films and the work of postcolonial critics like 
Bill Ashcroft, Gareth Griffiths and Helen Tiffin, based in Australia, who have written back from the periphery to the metropolitan centre (1989).

Dominique's 'Traces' prompted me to look for the place names on the map and read up their history and I felt that the poet was evoking places associated with Aboriginal people, while at the same time pondering on ecosystems in time and place. What stood out for me was the assertion: 'Traces/are geological I say Scars man-made'. This suggests to me the effect of human intervention today which takes on a new urgency considered against transformations caused in geological time, as the former erodes the environment with 'scars' signifying unhealable wounds, intensified by the image of a 'phantom limb'. The specificity of place, of manmade destruction of our habitat and the image of fire stayed with me.

\section{'Traces' by Dominique Hecq}

We were discussing ecosystems - how they need time and space And perhaps a name to exist

You'd pulled out the flyer from the glove box with your bandaged hand I imagined

it hurt the phantom limb Instinctively pressed my ticket of leave to my breast

(a scholarship - human ecology)

knowing we ought to have cleared

the air upon disembarking at Davenport

but pushed on Filled the car with white noise

Now that ropes of rain drop from the sky

we are trapped between grey walls rising

from the button grass plain like whales bursting out from the sea in unbroken succession

to a horizon of waves in a gale Traces are geological I say Scars man-made

You snort Sigh This is a place of gloom

Rain stops The car coughs onwards lifting

the weight of silence - the distance growing between us with each lake rock-rimmed tarn 
each valley mountain high plateau

and rusty Queenstown where pyritic smelters

long belched fire and smoke stripping leaves

off each flaming tree on each flaming hill

Strahan at last Tomorrow Sarah Island

where birds don't sing for the cries of ghosts

lashing past pink ears towards Hell's Gates

And finally beyond the rugged ranges

Lake Pedder where icy winds pick up

from dry tributaries ... since history left

off - vine-like tough as scrub its thorns

carving dots on surfaces and deep beneath

\section{'Hasdeo Arand' [1] by Bashabi Fraser}

Over the centuries these unfragmented dense forests

Have nurtured their exclusive cycle of inter-dependent life

Of grass and trees, birds and beasts, medicinal plants and herbs Multiple species in a rich texture of a wonderful wild world

Their silence welcoming ancient India's fraternity of Gonds Who have taken and given back in a solidarity with the trees

Which thrive on the mutual respect of nature, beast and humanity A magical thread that twines through life and holds it together

In a balance that is protective yet prolific, tested through time. But the commercial axe is ready to unleash the black smoke

Trapped beneath the undergrowth. It has started to devastate Parsa [2] where cavernous gaping wounds appear as the green

Is shorn and life is torn from the elephants' path as acres are claimed, Threatening to trash the abundance of bark, branches and roots,

Choke the tendrils and shoots, nipping their youthful dreams 
Even while they reach out to join a lingering, breathing community

Of hope. The arms of the Gonds which have plucked flowers and fruit, Grazed cattle and found medicines, shelter, livelihoods and comfort

In the continuity of their habitat, will be broken forever with a one-time Compensation which will steal nature from them and snap their life-bond.

The powerful arm of development reaches out from Ahmedabad, Encircling and choking an ancient forest in a neighbouring state

And crosses the Indian Ocean to claim the underground wealth At the Galilee Basin, endangering the delicate balance that exists

Where the Great Barrier Reef stretches its lavish maternal arm Along Queensland's coast, from where a railway line will stretch

To Abbot and Hay Point to ship the combustible rock to India's shores And the smoke from earth's caverns will spew over plains

Dispersing the rain clouds, polluting freshwater in Hasdeo river

Destroying the last vestige of live coral magic across the sea

Displacing the millions who have practised preservation

Conserving the energy that has fostered the earth.

\section{Reflection}

My response took me to the forests in the state of Chhattisgarh in central India where acres of forests are being cleared with Government sanction, to be replaced by open coal mines. The fire and smoke 'stripping leaves off/each flaming tree' in Australia, took me to the trees which will be felled and burnt in Hardeo Arand, the 'cries of ghosts' in 'Traces' were repeated in the threatened lives and livelihoods of the Gonds who have lived and protected the forests from ancient times and will be displaced by decisions made in the interest of transnational trade and thus become tomorrow's 'ghosts'.

I have been led by 'Traces' to adopt the unrhymed couplets in a poem which has sixteen stanzas. There is an Emily Dickinsonian touch in the poem with its dashes and parenthesis, almost like the stiches Dickinson used to stitch her manuscript pages together, though for me the dashes in 'Traces' read like stitches after a surgery. The open-ended nature of the last stanza without a full stop suggests a journey that has not ended, an experience which has not had a closure, signifying the slow violence that occurs over space and time. I have used some dashes, but unlike the original, I have used commas and concluded with a full stop to mark the finality of an irretrievable reality. 


\section{Second pair of poems: 'Fire relies on the leaves of gum trees' and 'Jhoom'}

I find the matter-of-fact reality embodied in the title 'Fire relies on the leaves of gum trees' chilling in its affirmation of a link between bush fires in Australia and the beautiful but brittle Eucalyptus. The innocence of the tree which we have known in the popular Australian song, 'Kookaburra sits on the old gum tree' is transformed by the image of an unstoppable conflagration that is aided by the very nature of the leaves of the gum tree which encourages the fire to spread in a chain reaction, which is brought about by climate change evident in rising temperatures. The reference to the 'smell of your burning skin', to the 'inferno' amidst which is a 'grave amongst blistered roots,' continues the image of the fire raging and destroying a familiar world where certainties turn to ashes. The inadequacy of words to express the scene, resisting 'the etiolation of language' conjures the terror of an unspeakable experience. I was reminded of the dualism in nature, as fire can be a saviour if managed with care, but a demonic force when it moves beyond human control, sustaining or destroying life, respectively. The choice lies with policy makers who can prevent slow violence through programmes which halt planetary degradation.

\section{'Fire relies on the leaves of gum trees' by Dominique Hecq}

No sound fits this spectacle No sound

but the hiss of fire bark grass

searing your world into sheer whorls

of alliterations Hallucinations

of words resounding with nothing

Following faultlines a gorge aflame

furrows erased in granite and sandstone

lines of scribble gums forever

receding The gorge

barring you

Now how could I speak again

when syllables shatter on my page

turning words inside out

when letters hover in the air

like the smell of your burning skin?

We were discussing poetics

on our mobiles How we didn't need

manuals for wordsmiths

preferred to work words as an end

in itself make a poem fulfilled 
in its enaction look inwards to the materiality of language on the page and in the mouth stress the event not the effect You said good bye

And now I dream that you flit out of my skin your voice lettering me Poetic enjoyment perhaps as if to resist the etiolation of language

Don't put individual utterances on show you say Perform their moves of repetition re-use reiteration show your reader the absurd desire to contain ( )

For here is the gum and its inferno remains the grave among blistered roots the mouthless earth lulling one to leave If it could speak it would say here is the silence here is the question

\section{'Jhoom’ [3] by Bashabi Fraser}

On the steep hillside of North East India Are neat terraced fields which bear grain, Vegetables and fruit on subsistence farms The testimony to focussed labour in small Holdings with a modest surplus for local markets.

The silent earth speaks to tribes when the soil Is exhausted, and they listen, moving to neighbouring Fields, leaving theirs fallow for the forest to return For the grass to grow again, for the land to be replenished When they can return and begin again the cycle of sustenance.

They slash and burn the forests, create the clearings As they have done for centuries, to sow seeds On the ashes of older fires which they once lit On terraces that have recovered their fecundity - 
Ready to give birth to new crops for the community.

These fires are hand-lit, life giving and controlled.

But far away, as climate change affects seasons,

The rhythm of tidal waves we once knew

Is transformed. From the churning Indian Ocean

Hot currents in the western waters cause floods

In Africa, while cold streams in the east diffuse

All hope of rain. Drought reigns in the Bush

Lightning sparks ignite the crisp dry branches

The wind catches embers and flits them across

To light new fires. Birds tumble into the flames

And koalas gasp for breath on Kangaroo Island

The fireballs rage through New South Wales and Victoria

A smoke pall lifts from the skeletal trees and mingles

With the coal burnt for power across a continent

Praying for rain, choked by the dunnest smoke of Hell.

\section{Reflection}

In 'Jhoom', my response to 'Fire relies on gum trees', I go back to the 'slash and burn' method of subsistence farming in North East India which the hill tribes have practised for centuries on terraced hillsides. This method ensures that the tired land recovers after being left fallow for a certain period before it is recultivated. The forests are allowed to grow back once the farmers have moved on to other fields.

Another reality unfolds across the Indian Ocean. The threat of opening up coal mines by burning the forests that have stood guard over the peat deposits in Australia, raises fears of endangering the Great Barrier Reef - a living coral stretch that holds the magic of biodiversity. A coal venture has been proposed by a transnational company which will benefit India through a railway line in Queensland which will bring the 'smoke' from one coast to another in a transcontinental journey across the Indian Ocean. It is the same company which is responsible for buying up swathes of forest in Central India for open cast coal mines.

The reality of the diverse hot and cold streams - the dipole that occurred in the Indian Oceans caused floods on one continent (Africa) and drought in another, resulting in the interminable fireballs that raged through the southern states of Australia between June 2019 and January 2021(known as the Black Summer), depleting life in their depths. The Bushfires led to mass graves of countless creatures amongst the 'skeletal trees'. This is the 'Great Derangement' that Ghosh warns us about and asks us to heed now before it is too late.

I have adhered to the five line stanza in Dominique's poem and have retained the six stanzas, but the silences signified in the spaces/gaps which are so profound in her poem on 'Fire', are 
not suitable to my response, as the 'Jhoom' method I commemorate ensures continuity (practised by indigenous tribes), rather than the silence that follows utter destruction of a devastating conflagration.

\section{Third pair of poems: 'Catch' and 'Witness'}

Dominique's poem 'Catch', dedicated to 'Julia', conjures the clarity of a day at the point where a river meets the sea. Once again I read a sense of loss and utter helplessness to avert a tragedy. The raised hand became my central image and the kelp in the water reminded me of the underwater mesh of visible roots of the Sunderbans in the Bay of Bengal. The list of birds foregrounded in italics in the last line conjured images of several migratory birds who are transnational denizens of the air, but who uproot themselves from their nests as seasons change and move across nation-state borders and continents with ease, to make their home elsewhere.

\section{'Catch' by Dominique Hecq}

For Julia

Smell the rain on the breeze down at the river mouth where fishermen stand in the swirl of incoming waters

Feel the first drops on your skin where the mystery of the ocean draws away from salt spray and the chill of the west wind

Ribbons of kelp sway in the deep

Refracted light dapples your face as the child comes up for air

Your hands, useless

against the sky

Arms, broken wings

skeleton dust

Osprey kestrel tern skua shearwater sandpiper swift 


\section{'Witness' by Bashabi Fraser}

The fisherman watches the dolphins

Frolic with the joy of freedom

At the Mohona, [4] where the freshwater

Meets the sea in the tide country. [5]

This is the moment to relax

Beyond the crocodile's gaping

Mouth and the tiger's crouching

Prowess and set his net afloat.

The tide comes with fierce intent

Sandbanks and islands disappear

The mangroves bend in obeisance

His hand is still

When the waters recede

The small minivet flutters

As the only witness here.

\section{Reflection}

In my response, one native bird becomes the sole witness in the land of the Mohona - the confluence where fresh and salt water meet. This is the land ruled by the tide, which is the place of migration and transformation as commemorated in Amitav Ghosh's novel, The Hungry Tide (2004) and again evoked in The Great Derangement (2016). The image of the helpless hand becomes the lifeless hand of the fisherman in 'Witness', who is at the mercy of the tide that engulfs him and recedes to reveal a landscape transformed by the sea.

\section{Concluding thoughts}

This project has established that a transnational 'dialogue' is possible for poets who have moved worlds and live on different sides of the globe. It has shown that even when unexpected personal events interrupt an intended exchange, a poetic interaction is possible as verse has the communicative power which defies the unexpected and unavoidable interruptions in time and space, bridging the 'unhealable rift' in an experience that is both enriching and rewarding for the creative process. It has helped us to see that we share similar concerns in India and Australia about the disruption caused to life, setting in motion a slow violence by profit driven commercial policies which intensify environmental degradation brought on by climate change. 
The gap caused by unforeseen circumstances in my life, has meant that I came back to Dominique's poems as a pandemic gripped the world which has come to a standstill with nations under lockdown and travel restrictions imposed across international borders. The earth seems to be fighting back, sending a strong message as industrial production and transport ground to a halt and the skies cleared as never before, filling our world with birdsong and the earth around us witnessed a verdant abundance. Rereading the poems by Dominique Heq against this new world reality which followed at the heels of Australia's devastating Bushfires, have prompted my responses to dwell with renewed interest on the themes of displacement, loss and environmental depletion and see how poetry can give voice to universal concerns. The periphery returns to rewrite the narratives of the centre, reaffirming the claim of the vulnerable to their habitat, which writer activists defend as they send out a plea to preserve the earth's resources for our future generations.

\section{Notes}

1. Hasdeo Arand is an ancient forest rich in bio-diversity and home to many tribes in India (e.g., the Gonds) who are conservationist in their relationship with the forest. The forest in Chhattisgarh state in Central India covers 170,000 hectares and is now threatened to be slashed down by licenses granted by the Central Government to a mining company that has started baring the earth in open coal mines, whose produce will intensify the atmospheric pollution in India for years to come.

2. The Parsa coal project is named after a village in the state of Chhattisgarh in India.

3. Shifting cultivation which uses the slash and burn method practised by many tribes in tropical regions. Etymologically, Jhoom originates from the Jhuma tribes of the Chittagong Hill Tracts in Bangladesh who practise this effective and sustainable form of agriculture that protects forests, encouraging regrowth, stops over-cultivation, sustains biodiversity and supports the livelihoods of poorer communities. This time-old method has been campaigned against and discredited by misinformed pressure groups, fully informed policy makers and industrial companies interested in commercial logging, forest clearance for mining, plantations and biofuel.

\section{Confluence}

5. The Sunderbans in the Bay of Bengal

\section{Works cited}

Ashcroft, B, G Griffith \& H Tiffin (eds) 1989 The Empire Writes Back: Theory and Practice in PostColonial Literatures, Routledge, London \& New York

Bhabha, HK (ed) 1990 Nation and Narration, Routledge, London \& New York

Dickinson, E 2016-2017 The Complete Poems by Emily Dickinson, CreateSpace Independent Publishing Platform

Ghosh, A 2004 The Hungry Tide, HarperCollins, London 
Ghosh, A 2016 The Great Derangement: Climate Change and the Unthinkable, University of Chicago Press, Chicago

Nixon, R 2013 Slow Violence and the Environmentalism of the Poor, Harvard University Press, Cambridge MA

Said, EW 2000 Reflections on Exile and other Essays, Harvard University Press, Cambridge MA Vertovec, S 2009 Transnationalism, Routledge, London 